\title{
REACTIVE DYES IN PROTEIN AND ENZYME TECHNOLOGY
}




\section{REACTIVE DYES IN PROTEIN AND ENZYME TECHNOLOGY}

Edited by

Y. D. CLONIS

T. ATKINSON

C. J. BRUTON

C. R. LOWE

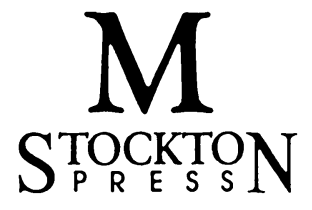


(C) The contributors 1987

Softcover reprint of the hardcover 1st edition 1987

All rights reserved. No reproduction, copy or transmission of this publication may be made without written permission.

No paragraph of this publication may be reproduced, copied or transmitted save with written permission or in accordance with the provisions of the Copyright Act 1956 (as amended), or under the terms of any licence permitting limited copying issued by the Copyright Licensing Agency, 7 Ridgmount Street, London WC1E 7AE.

Any person who does any unauthorised act in relation to this publication may be liable to criminal prosecution and civil claims for damages.

First published 1987

Published in the United Kingdom by

THE MACMILLAN PRESS LTD

Houndmills, Basingstoke, Hampshire RG21 2XS

and London

Companies and representatives

throughout the world

Typeset by TecSet Ltd, Wallington, Surrey

ISBN 978-1-349-06584-4

ISBN 978-1-349-06582-0 (eBook)

DOI 10.1007/978-1-349-06582-0

Published in the United States and Canada by

Stockton Press

15 East 26th Street, New York, NY 10010

Library of Congress Cataloging-in-Publication Data

Reactive dyes in protein and enzyme technology.

Includes index.

1. Proteins-Analysis. 2. Enzymes-Analysis.

3. Proteins-Affinity labeling. 4. Dyes and dyeing.

5. Dye-ligand affinity chromatography. I. Clonis, Y. D

QP551.R27 $1987 \quad 547.7^{\prime} 5046 \quad 87-21903$

ISBN 978-0-935859-26-3 


\section{Contents}

The contributors

vii

Preface

1 Introduction to the use of reactive dyes in biotechnology C. R. Lowe

2 The chemistry of reactive dyes

C. V. Stead

3 Dye-ligand chromatography

Y. D. Clonis

4 Large-scale dye-ligand chromatography

M. D. Scawen and T. Atkinson

5 High-performance dye-ligand chromatography

Y. D. Clonis and D. A. P. Small

6 Dye-ligand aqueous two-phase systems

G. Johansson

7 Metal ion-promoted dye-ligand chromatography

P. Hughes and R. F. Sherwood

8 The use of organic dyes in the elucidation of enzyme structures and mechanisms

J. E. C. McArdell and C. J. Bruton

9 Fractional protein precipitation using triazine dyes

J. C. Pearson 
Appendix: The disclosed chemical structures of some triazine dyes

Y. D. Clonis

Index

201 


\section{Contributors}

T. Atkinson,

Microbial Technology Laboratory,

PHLS Centre for Applied

Microbiology and.Research, Porton Down, Salisbury

C. J. Bruton,

Parke Davis Research Unit, Addenbrooke's Hospital Site, Hills Road,

Cambridge

Y. D. Clonis,

The Biotechnology Centre, University of Cambridge,

Downing Street,

Cambridge

P. Hughes,

British Biotechnology,

Wallingdon Road,

Cowley, Oxford

G. Johansson,

Department of Biochemistry,

Chemical Center,

University of Lund,

Lund, Sweden
C. R. Lowe,

The Biotechnology Centre,

University of Cambridge,

Downing Street,

Cambridge

J. E. C. McArdell, Microbial Technology Laboratory, PHLS Centre for Applied

Microbiology and Research, Porton Down, Salisbury

J. C. Pearson, The Biotechnology Centre, University of Cambridge,

Downing Street,

Cambridge

M. D. Scawen,

Microbial Technology Laboratory, PHLS Centre for Applied

Microbiology and Research, Porton Down, Salisbury

R. F. Sherwood, Microbial Technology Laboratory, PHLS Centre for Applied

Microbiology and Research, Porton Down, Salisbury 
D. A. P. Small,

C. V. Stead, Analytical Section, Dyestuffs Consultancy Service,

Research and Development Blackley, Manchester

Department, ICI,

Agricultural Division, Billingham, Cleveland 


\section{Preface}

The initial observations which led to the first use of reactive dyes in biochemistry predates the elucidation of the genetic code. As with so many critical but unusual and unexpected discoveries, the importance and breadth of applications were hardly even imagined in those early days. In the ten years immediately following the pioneering work, fewer than thirty papers were published on further applications. However, in 1976 alone we have details of thirty-two and the first century was recorded in 1979.

This rapid expansion in the utilisation of reactive dyes followed the combined realisations that the useful properties were not confined to just one or two dye molecules and that, in marked contrast to the earlier theories, the dyes could interact with a broad spectrum of proteins - from kinases to restriction endonucleases and from dehydrogenases to interferon. The research was given additional impetus by the wider availability of dozens of triazine dyes in suitable quantities for biochemical studies in the mid-1970s. All the researchers are greatly indebted to $\mathrm{Dr}$ C. V. Stead and his colleagues at the ICI Organics Division for much of this increased availability. We are also grateful for his contribution to this volume, on the basic chemistry of the reactive dyes - a subject which is frequently rather ignored by biochemists and biotechnologists to their cost.

The binding of Cibacron Blue F3G-A to dehydrogenases was first exploited in the development of new techniques for their purification. The entire family of reactive dyes is now used extensively in protein purification. If different species are counted, purification protocols for over a thousand proteins have been published. Two chapters on dye-ligand chromatography, one on the conventional scale and one on larger-scale applications, are very appropriate.

The dye-ligand technology is not limited to conventional matrices. HPLC supports have been modified to incorporate the reactive dyes to provide high-performance dye-ligand chromatography. This can also be operated on a preparative scale, and a further chapter describes these developments.

The binding of the triazine dyes to proteins can be affected by many other molecules and ions. These characteristics have led to dye-ligand 
aqueous two-phase systems and metal ion-promoted dye-ligand chromatography. Both these areas are described in this volume.

The observation that many enzymes were specifically eluted from 'dye columns' by substrates or inhibitors suggested that the dyes were mimicking some parts of the structures of those substrates and inhibitors and that they could be used as active-site probes in the elucidation of enzymes' structures and mechanisms. Some particular examples of this novel approach are discussed in Chapter 8.

The Editors thank all the authors for their contributions and hope that these examples will stimulate the readers into further innovative exploitation of these remarkable molecules.

C.J.B.

C.R.L. 